\author{
Pawel ARMADA \\ pawel.armada@gmail.com
}

\title{
IS THAT WEST OF US STILL THE WEST?
}

\section{A NOTE ON THE HUMANIST APPROACH TO THE QUESTION OF CONTINUITY VS. DISCONTINUITY}

The article takes up the concept of "Central Eastern Europe" only to show that ABSTRACT it makes sense if we can reshape our political imagination. What is crucial is our perception of the West which now is based on intellectual assumptions about the continuity of Western civilization. Rather, we should reflect on the role of discontinuity as the key to contemporary politics or, more broadly, to modernity. To explain this possibility, the Humanists' (Irving Babbitt's and Paul Elmer More's, preceded by Thomas Hulme's) approach is briefly surveyed, with special reference to the question of civilization vs. barbarism as the most relevant, or most urgent, distinction in the modern world. The main message is that we, the "Central Eastern Europeans," are very much in need of political realism. This ought to be, however, a type of realism based on profound philosophical insight, like that of the Humanists.

Key words: West, humanism, discontinuity, civilization 
1. The so-called Eastern, or Central Eastern, Europe is in fact an amalgam of different countries and traditions. We, Poles, have relatively little in common with, e.g., Romanians or Estonians. And, again, what we have in common with some other nations can be traced to those lessons of history that we would rather never have taken. There is just too much evidence that living together, alongside each other, in this part of the world is not the easiest thing on Earth. So, historically, we must be very careful not to offend each other. And geographically, we must take account of a great many differences as regards landscape, natural resources, and so on.

Be that as it may, the concept of "Central Eastern Europe" can be considered meaningful insofar as we can use it in the context of vivid experience. Actually, we need a powerful reason to think of ourselves as, above all, "Central Eastern Europeans." The experience needed here is likely to be understood in terms of an undesirable and fallen ideology: in short, we all remember communism. Or, more precisely, we remember being effectively conquered by the Bolshevik hordes - the Eastern barbarians - who then "looked after" us for several decades; being forced to accept the rules of a planned economy and policies we would not, at any time, choose for ourselves if allowed to make free choices; being occupied, persecuted, humiliated in many ways, and of course, forcibly separated from the West. But the nightmare is gone. We have overcome it. And that has been experienced in a similar way by the group of Central-Eastern-European nations. In general, it was not a sorrowful experience of breakdown, or collapse of the shared empire. As for the crucial issue of the transformation of the former Soviet bloc, the Russian perspective seems to be entirely distinct from ours; not only because "their" communism lasted for longer, and so they simply had more time to get used to miseries, atrocities, and incongruities of the system. Although no one can deny the fact that it is Russians who suffered most from the Bolshevik government and the Soviet bureaucracy, one also cannot doubt that the Russian people could identify themselves with the forces of the empire which remained, by and large, an alien structure to their "allies" from the Warsaw Pact.

The point is that Russia, together with the majority of the former Soviet "republics," cannot cease to be "Eastern." Apparently, since the end of the Cold War they have tried imitating the West - with a measure of success, to be sure - and maybe some of them desire to be able to change into Americans or Germans. However, this is impossible. They can build their own skyscrapers and drive fast and eat junk food and have a lot of real achievements, yet they cannot exchange the fathomless spaces of the Heartland for the pleasant shores of the Rimland, and still less, give up their identity as the people of, probably, the biggest empire in history. On the other hand, Poles, Czechs, Hungarians, etc. would tend to identify themselves as once victims, and now the gravediggers of the empire (with its ideology). We were beaten at first, but we won in the end. And the winner is one who no longer takes part in the miserable spectacle of Eastern politics being invited, instead, to the party of the rich and happy societies of the West. Accordingly, our political thinking reflects, in the main, this kind of experience: East is something we have just escaped from; West is something we are trying to catch up with. If so, the concept of "Central Eastern Europe" should serve to indicate the situation of 
the countries running in between, on the way to becoming "fully" Western; the "new" ("younger") Europe, in other words the Europe to be completed.

Such a concept stands or falls on a specific vision of the West. Now, let us distinguish the two levels of political thinking, or political imagination, in regard to this question. The first level can be depicted as the field of popular opinion. For a long period, we who lived on the bad side of the Iron Curtain found ourselves economically, and socially, retarded in comparison to the West - namely, the West of our dreams. West of us, there was room for freedom and satisfaction. East of us, there were absurd limitations on freedom and constant shortcomings. West of us, there was "Star Wars." East of us, there was Chernobyl. The choice for the West has, first and foremost, been the choice for wealth; the wealth at hand, as it seemed, accompanied by prospects for successful (and safe) development. All this could be summed up in the title of the 1989 Polish movie, 300 mil do nieba (300 Miles to Heaven). Western Europe - to say nothing about the USA - would appear to many as a sort of Promised Land. And then, gradually, the simple enthusiasm for the West began to wane. This does not mean, for sure, that we stopped being enthusiastic at all, turning our eyes to the East, again. No. Actually, the East does no longer exist in our imagination, except for a vague memento or a symbol of danger and fall. There is no serious longing for Muscovite patronage, but there are many doubts about Brussels (or Berliner) patronage at the moment. Lots of young people who left for the West do not, on the whole, bring back news of the paradise. We now have become very conscious of Western social issues and the general discontent. We are plainly scared about the Islamists, and often repelled by certain ideological actions, if not by the overall idea of "political correctness." And, last but not least, it dawns on us that we are not loved by the peoples of the "old" Europe with a disinterested love for humanity. We are not beloved nice kids anymore. Inevitably enough, we are gaining maturity as fellow-citizens of Western Europeans.

Of course, it is natural that the opinions of society fluctuate: our everyday life consists of hopes and retreats; when we are given possibilities to follow, we try them. And it is natural, too, that we choose being prosperous, and not necessarily ponder over fundamental choices in the background of our lives. Yet, at the same time, we can refer to the second level of imagination, or thinking about politics: the field of intellectual discourse. Here our daily experience meets a theory (and can be reinformed by a theory). Any such theories - any significant discourse - originate in the works of a few educated people. These, in turn, are not visitors from space, ones being without prejudice whatsoever; their minds, too, contain "ordinary" visions of wealth and prosperity. Or else, who does not wish to be satisfied, or free to look for satisfaction? You can state, however, that in the case of the educated (the so-called intelligentsia), not only material goals usually come to mind, and freedom does not amount to an increase in salaries and easy shopping. For them, our choice for the West should be justified, primarily, as the choice for a better (or truer) type of civilization.

When it comes to the question of civilization, our sense of history is brought to light. As educated people, we like to tie the present day with the triumphs and failures of the past, and explain the latest tendencies, or developments, in light of primeval 
dreams which appear to be slowly coming true. Thus, the better (or truer) type of civilization may be described in terms of a response, conscious and deliberate as it seems, to the centuries-old legacy of hope; the hope for peace, welfare, dignity, and so on. We need not be advocates of the philosophy of history (Marxist, Hegelian, etc.), in a strict sense, to follow such a path of thinking. What we need intellectually, rather, would be a more ambiguous assumption that our reading of the past was basically correct, and that nothing to be found in records from the past could make our present achievements trivial, wicked, or invalid; that our "modernity" be justified in itself. On the other hand, as regards Western Europe (but not the USA), we stand before the visible evidence of ancient glory and vital spirituality: classical literature, Gothic cathedrals, the arts in general. The everlasting beauty of Venice and Florence, for example, is beyond any doubt. We are, furthermore, impressed by Western European history - the history of its cities and countries - and, accordingly, seek to connect the exceptional heritage of the "old" Europe's nations with their current shape. We may dislike certain trends, and resist the fads of the day, but we "know" that the genuine heart of the civilization we want to belong to is still there. In a word, we are inclined to perceive continuity: from Socrates to Sartre and Habermas, from the Church Fathers to Teilhard de Chardin and Bultmann, from Dante to Houellebecq and Grass, from Charlemagne to Macron and Merkel, from Gregorian Chant to contemporary radio playlists, and so forth. Hence, not only does the authority of the West - from our "Central Eastern" perspective - result from their ability to become and remain, reportedly, the wealthiest part of the world, but from this living continuity of the human civilization that they form through the ages. And while popular opinion is susceptible to change due to various economic and social conditions, intellectual discourse seems more stable, in fundamental respects. We can only stress, if necessary, that we do not come to the West from nowhere; that we were, not so long ago, the part of the Western crew (though the less important part), and this is simply our comeback here. Back to the company of Socrates, the Church Fathers, and the rest.

However, the very idea of continuity should be critically reflected upon. Otherwise, our intellectual discourse will be not very helpful, to say the least. Let us emphasize, at once, that critical reflection of this kind must not be taken for a mere occasional moaning and groaning about politics (economy, culture) which is so typical and obvious in the field of popular opinion. Our thesis cannot even be reduced to an observation that there are problems concerning, say, the moral conduct of Western societies, following the "revolution" of the 1960s, the demographic crisis, and the like. Some of us, if asked the question, "What's now wrong with the West," will answer: "Its inhabitants have now become decadent." And, most probably, they will refer to phenomena revealed in the last decades, if not recent years. This way, our sense of history remains untouched because we still think in terms of continuity, even though we would prefer to treat the current phase as somehow unfortunate. At any rate, to be sure, this is_the Europe of the classical philosophers and Christian theologians, the Europe of Pérotin and Dante Alighieri, the Europe of universities... - isn't she? Well, not necessarily so. 
A funny English idiom reminds us of the danger of being unable to "see the forest for the trees." Here, that is to say, we need to take enough distance from contemporary (and local) troubles to have a vision of the civilization as a whole. This is a very difficult task, indeed. Only a few perform it well. Almost a century ago, Irving Babbitt (the main protagonist in the American Humanist Movement) wrote about the distinction between the mere visionary and the man of vision (...) Where there is no vision, we are told, people perish; but where there is sham vision, they perish even faster. The worst difficulties of the present time arise (...) even less from lack of vision than from sham vision. Otherwise stated, what is disquieting about the time is not so much its open and avowed materialism as what it takes to be its spirituality. The multitudes always long for wealth or immediate bodily pleasures. This is true in reference to all possible societies. The real question is what they believe, or are taught to believe, in. This is a question about envisioned ideals, or "first principles," which represent a steadier - spiritually established - characteristic of the civilization. Babbitt declares: In general I commit myself to the position that we are living in a world that in certain important respects has gone wrong on first principles; which will be found to be only another way of saying that we are living in a world that has been betrayed by its leaders. Now, an impression may arise that in seeking to challenge the sense of history as mentioned above, we just try to express a yearning for a "Golden Age" of Europe. But can anyone living today hope for return of the feudal system, religious wars, the Plague? Apart from moral issues, it would be unwise to pretend that we could live just in the way our ancestors did. No, the critical reflection on the continuity does not mean an idealization of the past. The core of the matter is grasped, rather, by Babbitt when he explains: The leaders of the past have most frequently been bad in violation of the principles they professed, whereas it is when a Robespierre or a Lenin sets out to apply his principles that the man who is interested in the survival of the civilization has reason to tremble. ${ }^{2}$

Let us stop, however. Is this still relevant to our topic? Does it make any sense to hold that, for instance, Mrs. Merkel may be placed by the side of Robespierre and Lenin? The point, to reiterate, is to see the forest. Many of us, the educated, are familiar with critical diagnoses of modernity. We are conscious, in particular, that some crucial aspects of modern political thought have been harshly criticized by a number of primary thinkers. They brooded, above all, over political catastrophes of the $20^{\text {th }}$ century; they studied the theory and practice of the totalitarian regimes which they often knew first-hand. There is much wisdom in their legacy, no doubt. There is, nonetheless, room for illusive self-assertion as well. Both totalitarianisms, Nazi and Bolshevik, have long since been defeated, materially and spiritually. If we compare our conditions of life in whatever part of Europe, or even globally - to those provided for totalitarian societies, we can only contemplate the unspeakable cruelty and injustice, and thank to God that we live in better times. But this is ambivalent: on the one hand, we are confident

Cf. L. Strauss, "Social Science and Humanism”, in L. Strauss, Th.L. Pangle, The Rebirth of Classical Political Rationalism: An Introduction to the Thought of Leo Strauss, Chicago-London 1989, p. 5.

2 I. Babbitt, Democracy and Leadership, Indianapolis 1979, pp. 38, 47, 292. 
in rejecting the evil solutions of modern theory and practice, and find them the most unacceptable excesses of human thought and emotion; on the other hand, we are prone to think of those phenomena as something accidental, so to speak, and as worth being remembered as belonging to the past. It is, for example, easier to connect the ideological performance under Hitler or Stalin with a form of religious experience (and talk about a secularized "political religion"), than to see a similar connection between our democratic beliefs or "lifestyles" and ancient cults or myths. At the most fundamental level, such thinking betrays a fallacy - typically modern - that we are becoming, anyhow, more rational, or sensible, than our predecessors. More explicitly, it appeals to our sense of history: historia magistra vitae est; so we must be cautious enough to avoid the terrible mistakes of "a Robespierre or a Lenin." What else are they, in themselves - masters of terror and totalitarianism - than several notes of dissonance, so unacceptable as they could be, within the symphony of humanity's development? However tragic the events we may recall, can it cause us to deny the progress of the whole civilization (and especially, Western European civilization)? The progress, namely, in the field of science or technology, together with economic and political change; everything, in a word, that we have won through the "modern experiment," once set in motion in the West. So the ground for our sense of history, our essential perception of continuity, can be kept almost intact. But is it really so? Are the "first principles" (not methods!) of the leaders of the contemporary liberal democratic state (or society) fundamentally different from the "first principles" exercised so badly by the villains of modernity? Is there a bright side of the moon, so to say, at all?

Well, most probably, we cannot demand a simple answer to such a question. But maybe we should attempt to understand those great thinkers whose propositions appear to be completely at odds with the main current of modern thinking; who, at the same time, did not claim to be "mere" traditionalists, defenders of "the past" (understood as a lost cause), "the last of the Mohicans" in philosophy or theology. From our perspective, it would be better, moreover, if those sages had lived recently enough to become witnesses to the inception of the $20^{\text {th }}$ century, and early enough, not to be counted among the children of that age (reacting against totalitarianisms). This is exactly the case of the founders of the American Humanist Movement (almost forgotten nowadays): the already quoted Irving Babbitt (1865-1933), and his friend Paul Elmer More (1864-1937). Yet before we try to sketch, in a very concise manner, their diagnoses of modern Western civilization, let us turn to another interesting figure.

2. Thomas E. Hulme (1883-1917) was an English poet and thinker, and actually, a young eccentric, who died on the battlefield in the World War I, being thoroughly disillusioned with all of modern philosophy. In his never-completed Speculations we can read a powerful account of his intellectual awakening: I remember being completely overawed by the vocabulary and scientific method of the various philosophers of the Marburg School, and in particular by Herman Cohen's "Logik der reinen Erkenntniss." But one day, hearing Cohen lecture on religion, where his views are, as is well known, entirely sectarian, I realised very easily that the overwhelming and elaborate method only served 
to express a perfectly simple and fallible human attitude. This was very exhilarating and enlightening. One could at last stand free, disentangled from the influence of their paralysing and elaborate method. For what was true of their work in religion was also true elsewhere. It becomes possible to see a good deal of Cohen's work as the rigid, scientific expression of an attitude that is neither rigid nor scientific, but sometimes romantic, and always humanist. One can illustrate the effect of such work on the mind by this parallel. A man might be clothed in armour so complicated and elaborate, that to an inhabitant of another planet who had never seen armour before, he might seem like some entirely impersonal and omnipotent mechanical force. But if he saw the armour running after a lady or eating tarts in the pantry, he would realise at once, that it was not a godlike or mechanical force, but an ordinary human being extraordinarily armed. In the pantry, the essence of the phenomena is not arms, but the man. When you have recovered from the precision and refinement of the method in such philosophers, you will be able to recognise the frequent vulgarity of their conclusions. It is possible to combine extreme subtlety in the one, with exceeding commonplaceness in the other. ${ }^{3}$ Saying this, Hulme takes the stance of a rebel, one who devotes himself to the task of deliverance from the modern house of bondage.

According to him, our thinking - over a hundred years ago, to be precise - had been totally dominated by "the large class of pseudo-categories." We are all of us under the influence of a number of abstract ideas, of which we are as a matter of fact unconscious. We do not see them, but see other things through them. These "pseudo-categories," or "abstract ideas," can be traced to an unquestionable - as prior to the discourse that we know - demand for satisfaction. In short, we moderns become intellectually (or spiritually) satisfied only insofar as we see "the principle of continuity" in action. The destruction of this conception is, on the contrary, an urgent necessity of the present (...) We now absorb it unconsciously from an environment already completely soaked in it; so that we regard it not as a principle in the light of which certain regions of fact can be conveniently ordered, but as an inevitable constituent of reality itself. When any fact seems to contradict this principle, we are inclined to deny that the fact really exists. We constantly tend to think that the discontinuities in nature are only apparent, and that a fuller investigation would reveal the underlying continuity. This shrinking from a gap or jump in nature has developed to a degree which paralyses any objective perception, and prejudices our seeing things as they really are. For an objective view of reality we must make use both of the categories of continuity and discontinuity. Our principal concern then at the present moment should be the re-establishment of the temper or disposition of mind which can look at a gap or chasm without shuddering. ${ }^{4}$ What Hulme has in mind, first and foremost, are "general theories about the nature of reality," which parade as "philosophical" ("armoured") discoveries of the modern mind despite being nothing more than established "worldviews" that conceal nature of things. However, what can be most

T.E. Hulme, H. Read, Speculations: Essays on Humanism and the Philosophy of Art, London-New York 1936, pp. 19-20.

$4 \quad$ Ibid., pp. 3-4, 37. 
interesting for our purposes, is his use of the concepts of continuity and discontinuity in respect to the history of the West.

The key to the modern mind, and what follows, the foundation of modern Western civilization, lies in the sphere of religion. This means that the true understanding of religious philosophy which preceded the Renaissance makes the essential unity of all philosophy since seem at once obvious. It all rests on the same conception of the nature of man, and exhibits the same inability to realise the meaning of the dogma of Original Sin. Our difficulty now, of course, is that we are really incapable of understanding how any other view but the humanistic could be seriously held by intelligent and emancipated men, or assuming that an intelligent man might not be a humanist. In Hulme's opinion, what he calls "the religious attitude" has a primary advantage over what he calls "humanism," that is, our modern attitude that derives from the presupposed "canons of satisfaction." Historically, both these "attitudes" are continuous in themselves, and discontinuous to each other (so there must be a critical break in the history because of the replacement of the attitudes) - with the only difference being that the first one proves to explain reality, while the other produces a distorted imagination, ideologies etc. I hold, he says, quite coldly and intellectually as it were, that the way of thinking about the world and man, the conception of sin, and the categories which ultimately make up the religious attitude, are the true categories and the right way of thinking (...) I have none of the feelings of nostalgia, the reverence for tradition, the desire to recapture the sentiment of Fra Angelico, which seems to animate most modern defenders of religion. All that seems to me to be bosh. What is important, is what nobody seems to realise - the dogmas like that of Original Sin, which are the closest expression of the categories of the religious attitude. That man is in no sense perfect, but a wretched creature, who can yet apprehend perfection. The quest for perfection according to the pre-modern "attitude" is vertically oriented; it cannot be achieved but "upwards," in opposition to ordinary life: The divine is not life at its intensest. ${ }^{5}$ The orientation of "humanism" remains all the way horizontal; man is to be made perfect by just living and moving around.

What is the meaning of all this? Hulme's bold narrative enables us to grasp the distinctive feature of modern thought (and the modern life as it stems from thinking). That is to say, the substitution of the new eschatological ("satisfactory") perspective, of a continuous development or expansion, for the old religious dualism with its concentrated perception of the real (vertical) discontinuity: between God and man, or what is best and what is natural in the human being. The decisive break happened in Early Modernity, even if its results became substantial and transmittable, step by step, from "the few" to the multitudes, later - especially during the $19^{\text {th }}$ century. Romanticism, for example, confuses both human and divine things, by not clearly separating them. The main thing with which it can be reproached is that it blurs the clear outlines of human relations - whether in political thought or in the literary treatment of sex - by introducing in them the Perfection that properly belongs to the non-human. ${ }^{6}$

$5 \quad$ Ibid., pp. 8, 12-13, 70-71.

6 Ibid., pp. 10-11. 
3. The difficulty with Hulme, besides his hoping naively for a truly scientific philosophy (as distinguished from intellectual justification of a given Weltanschaung, worldview), concerns his use of the word "humanism" and its derivatives. For him, "the $\mathrm{Hu}$ manist attitude" connotes a general denial of human imperfection, so that romantic extravagances would only indicate a special mode of thinking "humanistically." In the eyes of More and Babbitt, such a perspective betrays a profound misunderstanding. What Hulme denounces as "humanism" is, in fact, the modern "cult of humanity" humanitarianism. As Babbitt says, with the decay of the traditional faith this cult is coming more and more to be our real religion. ${ }^{7}$ In his early novel, More adds with emphasis: Thou shalt love God with all thy heart and thy neighbour as thyself, was the law of Christianity. We have forgotten God and the responsibility of the individual soul to its own divinity; we have made a fetish of our neighbour's earthly welfare. We are not Christians but humanitarians, followers of a maimed and materialistic faith. This is the ideal of the world to-day... ${ }^{8}$ Humanitarianism thus replaces Christianity as the religion of the West - and holds sway over the Western mind. Humanism, on the contrary, may be understood as an idea, or practice, not inimical to (and not imitating) the pure "traditional faith," but rather a secular companion to that faith. And like Christianity, it has long been misused or simply neglected by societies living under humanitarian principles.

It will be useful now to ask how the Humanists (More and Babbitt) deal with the question of continuity vs. discontinuity. But first, what must be stated as clearly as possible is that they were not philosophers of history in the manner of those who believed in the "historical inevitability." Real philosophers - those who teach humanism, with no interest in flattery - are not only speakers for their age or culture. On the deepest level, human nature is not subject to change, and the human mind always confronts the same fundamental issues. ${ }^{9}$ There is a temptation for reason, in any epoch, to disregard the lessons of experience, or preventive common sense, and wave aside some of "immediate data of consciousness" in favour of creating "the" system which would presumably explain everything. If More and Babbitt did not trust metaphysical abstractions of any kind, they also did not assume an apocalyptic pose. The world (state, society) we live in is not born out of necessity: neither an obvious result of progress, nor an unavoidable stage of the Fall; nothing pre-established from below or above - as far as we can think it through. Here, again, lies the difference between Hulme and the Humanists. In the former, we have the replacement of "the attitudes." Actually, the false takes the place of the true, so the history of the West simply marks the horrific decline. The latter may be extremely critical as regards the actual "modern movement," for it must be judged as "humanitarian." Yet, at the same time, we are made conscious of the subtle coexistence of ideas, so to speak, that transcend the limits of modernity. In other words, what you believe remains a matter of choice (up to a point, and provided that you are gifted

I. Babbitt, Literature and the American College; Essays in Defense of the Humanities, Boston-New York 1908, pp. 34-35.

8 P.E. More, C.M. Harris, The Jessica Letters, An Editor's Romance, New York-London 1904, p. 54.

9 Cf. P.E. More, The Christ of the New Testament, Princeton 1924, p. 4. 
enough and able to seek for something not readily at hand). Hence, the main stress is put on the responsibility of the individual. Which means, in practice - the responsibility of "the leaders."

With the Humanists, we should also perceive a critical break. But this is not so much between the ages as between the different articulations of moral and religious experience. According to More, the serious rift is not between Christianity and Platonism, but between the common Greek sense of religion as it developed unchanged at the core through all the changes of the eight hundred years from the death of Socrates to the death of St. Chrysostom, and as it persisted, though with graver alterations, in the western world until a comparatively recent date - the great chasm is between that religious spirit and the prevailing modern ethics. The difference is in the attitude towards the distinctive reality and importance of the soul. ${ }^{10}$ For the classics, that is to say, the soul is saved by spiritual "self-care" (with or without God's support), by means of self-control (over passions or desires) or self-restraint. We must not be satisfied with our instinctive life and just follow the impulses of the moment, unless we do not deserve being called "human" at all. In Babbitt's words, if a man is to be truly human, he cannot expand freely along the lines of his ordinary self, but must discipline this ordinary self to a sense of measure and proportion. But most people, says Aristotle, do not wish to do anything of the kind (...) so that humanists in both the East and the West oppose to the democratic doctrine of the divine average the doctrine of the saving remnant (...) the maintenance of civilization is due, not primarily to the multitude and to some "general will" in Rousseau's sense that emanates spontaneously from a supposedly divine average, but to a saving remnant or comparatively small number of leaders. ${ }^{11}$ Regardless of any spells, any humanitarian formulae, or visions of a homogenous society, humanity proper does not belong to everybody. Humanity is a task, an all-too-individual enterprise, the result of $m y$ work on $m y$ soul. It is not so easy, then, to be counted among human beings because only the best of us can truly govern ourselves.

And where is the discontinuity? We may find it between "the higher" and "the lower" self, in the Humanist vocabulary, or between the domains of "the human" and "the natural" (roughly, in the sense of "the physical") laws. However, for all practical purposes, we may relate this experience of the "no longer" - fatal, as it seems, to our sense of history and the following assessment of the West - to the difference between civilization and barbarism. It is well-known that people of the past, and even classical writers, used to associate the word "barbarian" with those living outside the walls of the city; with foreign "cultures," as they call them today. The Humanists would rather trace such associations to the the primary, common-sense objection against the life that lacks order and purpose. It does not point, in the first place, to the weakest from nature; quite the contrary. Men and women of any race, of any descent, can be exceptionally gifted and mentally strong - in a word, born to be leaders - yet, at the same time, they may turn out to be epitomes of "moral indolence," incapable of spiritual "self-care" or

10 Idem, The Religion of Plato, Princeton-London 1921, pp. 299-300.

11 I. Babbitt, "Humanistic Education in China and the West", The Chinese Students' Monthly, vol. xvii, Nov 1921 / June 1922, pp. 89-90. 
strenuousness. So it would be pointless to consider them true leaders, and a society which they happen to lead - the civilized society. Those real barbarians cannot rule the state as they are not able to rule over themselves. They are slaves, in fact; slaves to their passions, desires, moments and circumstances of life. That means, slaves not only to their animal instincts but some "higher" impulses as well. Religious or "spiritual" aspirations, even if motivated "vertically," if unmeasured, are often pernicious and destructive for society. Thus, in More's view, asceticism is the attempt to attain the mystical release by violence rather than by the gradual discipline of philosophy and morality (...) liable to an equally violent relapse into uncontrolled impulses. ${ }^{12}$ Civilization does not depend on antinomian mystics or ascetics any more than it depends on wolfish "horizontal" expansionists. It depends, instead, on the example of the gentleman, or the aristocrat properly so called, who represents the virtues of humanism, like prudence or moderation; the virtues of the man who is responsible enough to concentrate on his own character. This true concentration comes at the price of immediate pleasures. Moreover, the gentleman acts with no regard to the applause from the multitude.

Although human nature is in essence invariable, men and women's decisions vary. As natural beings, we are necessarily limited and have to face our limitations in order to live and expand (as a matter of fact, staying alive equals expanding). As beings capable of civilization (which enables seeking perfection, or the good life as understood by the classics), we are free to ascend from the realm of necessity - even though we must obey the "law of measure," or human law, to be successful in such an effort. Man is, as Nietzsche says, the being who must always surpass himself, but he has - and this is a point that Nietzsche did not sufficiently consider - a choice of direction in his everlasting pilgrimage. ${ }^{13}$ Therefore, we can look at the civilization as an extension of individual discipline, or spiritual strenuousness, on the level of society or politics. From a such a perspective, it appears to be at risk - always. More writes that we are prone to forget that civilization has always been a tour de force, so to speak, a little hard-won area of order and self-subordination amidst a vast wilderness of anarchy and barbarism that are continually threatening to overrun their bounds (...) civilization is like a ship traversing an untamed sea. ${ }^{14}$ There is, in other words, a profound connection between civilization and humanism. If used with seriousness, the word "humanist" denotes a very rare type of being: one most human. The humanist seems to be the teacher of gentlemen or aristocrats. His main skill is that he is fluent in the art of mediation. We may suppose that he (the humanist) mediates between the extremes, and rightly so. However, it would be thoroughly misleading to conceive a purely formal scheme of mediation: one should be prudent and moderate in everything. As Babbitt declares, when the first principles are involved the law of measure is no longer applicable. One should not be moderate in dealing

12 P.E. More, "Definitions of Dualism", in P.E. More, Shelburne Essays Eighth Series: The Drift of Romanticism, New York-Boston 1913, p. 293.

13 I. Babbitt, Rousseau and Romanticism, Boston-New York 1919, pp. 245-246.

14 P.E. More, "Academic Leadership", in idem, Shelburne Essays Ninth Series: Aristocracy and Justice, Boston-New York 1915, pp. 41-42. 
with error..$^{15}$ The "first principles" is what we truly believe in; these are products of the imagination that work upon human instincts or desires. Then, we return to the sphere of religion and the vertical dimension of thinking. Why?

The difficulty of humanism, More explains, is to determine what shall be reckoned fair and wise, and to settle the true point of moderation in the sliding scale between vicious extremes (...) and in that ever urgent dilemma a true humanism will temper the insistent desires of nature, and correct the tendency to pursue the easier downward course, by keeping one eye (...) upon the supernatural heights. ${ }^{16}$ To simplify, the humanist is in need of a real faith, one capable of "moving mountains" - not by focusing on worldly affairs, but by renouncing the world. At the same time, he (the humanist) is acting to make religion, say, bearable for society; to make religion civilized. In any case, he really needs a vertically oriented "attitude," that dwelling "above," a heaven of the spirit, from which he derives ideal patterns of conduct, or character, based on spiritual concentration, to have them opposed to the sphere of natural necessity "below." So his art is the art of mediating between the true ideal and true (physical) nature; not any mediation, any ideal, any view of nature. On the other hand, the humanitarian gives, in a way, a parody of the humanist art, so that the ideal and nature change places. Hence the modern cult of humanity as understood in terms of natural (necessary) expansion.

Now, it is crucial for us to begin to see the humanitarian - and no longer humanist - quality of the West. According to Babbitt, the Western traditions have been partly religious, partly humanistic. Let us look, for a moment, at his account of studying the process of emergence of our "discontinuous" modernity: It has been my business for many years past, in connection with the teaching I have been doing at Harvard, to study the nature of the European Renaissance or break with the mediaeval past that took place in the sixteenth century and to trace the main currents of European thought and literature from that day to this. I have been giving special attention to what one may term the second great forward push of individualism, or emancipation from traditional standards, that took place in the eighteenth century. The characteristic of this occidental movement, as I see it, has been, from the sixteenth century down, its tremendous expansiveness. It has been, first, an expansion of men's knowledge and control of natural forces in the interests of comfort and utility. This first or utilitarian side of the modern movement already has its prophet in Francis Bacon; you may know its votaries by their pleas for organization and efficiency, and in general by their confidence in machinery. The second side of the great expansive movement puts its main emphasis on emotional expansion. and stresses at one time the fraternity that is to be achieved by this emotional expansion, at another time, the self-expression that it encourages. This emotional side of the movement had its prophet in the eighteenth century in Jean-Jacques Rousseau. To bring together the two sides of the movement, mankind as a whole is to advance constantly in the control of nature to the ends of

15 I. Babbitt, "Humanism: An Essay at Definition", in Humanism and America: Essays on the Outlook of Modern Civilization, N. Foerster (ed.), New York 1930, p. 32. Cf. Babbitt, Democracy and Leadership..., pp. 46-47.

16 P.E. More, The Christ of the New..., p. 136. 
utility and comfort, and at the same time is to be united increasingly by the spirit of brotherhood conceived as a process of expansive emotion. This movement may be defined in its totality as humanitarianism. ${ }^{17}$

As we see, the "humanitarian movement" has its origins in the Western European context and nowhere else. This does not mean that it stopped there. Just the reverse - the humanitarian "first principles" have been internalized, implemented, and imposed throughout the world. We cannot assume, in this age, that any serious political entities (or cultures) survive with no connection to humanitarianism, on the lines of pre-modern traditions. The discontinuity is to be found everywhere as the utilitarian-sentimental movement (...) professes to be civilized and ethical, and in the name of its own conception of civilization it always is ready to discard traditional ethical conceptions whether humanistic or religious. ${ }^{18}$ But a simple question can be asked as well: "Is there something like a humanitarian civilization at all?" When we think in terms of technological advances ("machinery"), or economic success, it looks sure that the answer must be "of course there is." Whatever difficulties may arise in the modern economy, in or outside Europe, it should be described as an "economy of plenty," one incredibly thriving in comparison to anything that had existed before. The Humanist, however, does not believe in the progress of mankind (as distinguished from the progress of the individual in "surpassing himself"). Babbitt himself refers to an interesting statement by John M. Murry, an English critic and journalist, who wrote right after the World War I: There would be not the faintest trouble in reading modern history in such a fashion that the disaster of the war would appear not a terrible aberration of mankind, but the logical culmination of all that process of complicating and multiplying material satisfactions which began with the Industrial Revolution in England and has usurped the name of civilisation. This so-called civilisation, it could be clearly shown, has acted merely as a multiplying instrument. It has increased the desires of man, and increased the horrors of the method he has always chosen to attain them if unimpeded satisfaction were not permitted. In himself, man is neither better nor worse than he was two hundred years ago, but he is by the material discoveries of labour saving methods, and the pseudo-moral discovery of the nation (which is hardly more than the national army) a thousand times stronger than he was. ${ }^{19}$ Therefore, civilization as we know it - and we know it nowadays only to a greater extent, and more specifically, than it was known in Babbitt's times - can be regarded as "a material condition," whereas the proper use of the word should rather be spiritual. If so, the West may no longer be the West; the further from its spiritual source (religion and humanism), the less identifiable it is now with the civilization it used to be, regardless of its wealth and heritage preserved. As a result, not only does our essential perception of the continuity, our sense of history, become, in the main, meaningless; our political imagination must also be revisited. To put it bluntly, caution is needed. It is possible to keep looking very civilized and be breaking down, at the same time, into

17 I. Babbitt, Humanistic Education..., pp. 85-86.

18 Ibid., p. 87.

19 J.M. Murry, The Evolution of an Intellectual, New York 1920, p. 168. 
barbarism. And this is not only a German story, to be sure. And not, as it seems, an obsolete history.

Certainly, before making any political choices, it will be necessary to understand more about the modern "religion" of humanitarianism. Philosophically, it consists of naturalistic assumptions (man is fully perceived and studied as a part of nature) and "divine" enthusiasm (based on the belief that there must be some redemption in the unity with nature). On the surface, it usually appears very optimistic about the natural instincts of men and future prospects for humanity. But when it comes to disillusion, a morbid state of melancholy is the sole response; since apart from the surface, the humanitarian attitude turns out to be, above all, fatalistic: the higher has to be surrendered to the lower for the sake of endless expansion - this is the law substituted for the ancient piety and the humanist "law of measure." What is crucial, then, about humanitarianism is that it stems from naturalistic monism: only the physical is real; there is no being and purpose beyond the realm of things which is the realm of necessity. However, in practice - and especially in the context of political imagination - humanitarians appeal not to a stern naturalistic monism, but rather, to a new version of "religious" dualism. This modern dualism, created primarily by Rousseau, amounts to an opposition between the individual and society, or maybe, between a new "emancipated" humanity and an oppressive society of the past, and so between the new and old civilization. Thinking along this line, we begin to grasp the foundations of the familiar rhetoric of progress, development, and mass liberation.

In Babbitt's opinion, the utilitarian debasement of general terms (to make them useful in the process of economic expansion) is only half a story; the sentimentalist has also tampered with the right meaning of words in his endeavor to prove that it is possible to satisfy the requirements of the moral law by some process of emotional expansion. All other modem revolutions were preceded about the middle of the eighteenth century by a revolution in the dictionary. ${ }^{20}$ Most notably, according to the new ethics, virtue is not restrictive but expansive, a sentiment and even an intoxication. ${ }^{21}$ The very notion of "the good" became interpreted "in terms of expansion" and no longer "in terms of concentration." No wonder that pre-modern approaches to the prime ethical question seem to us "astringent," if understood at all. ${ }^{22}$

Many of us are attracted by the vision of modernity as the age of freedom; the vision that we like to apply, first and foremost, to contemporary Western societies. This freedom to think and act in different ways may, in turn, be considered a source of conflict - yet it seems to be a reasonable price for not being a slave, doesn't it? Well, not necessarily so. As More says, to the superficial observer in might appear, in fact does appear, that the acknowledged distractions under which the artist, with the rest of us, suffers is the result of conflicting theories of life; but a closer study of the phenomena will show (...) that we are

20 I. Babbitt, Humanistic Education..., p. 88.

21 Idem, Democarcy and Leadership..., p. 143.

22 Cf. Idem, "Interpreting India to the West", in I. Babbitt, F. Manchester, F. Giese, W.F. Giese (eds.), Spanish Character and Other Essays, Boston-New York 1940, pp. $151 \mathrm{ff}$. 
rather under the sway of a single philosophy (that is, the intellectual basis of the entire humanitarian movement) which bears in itself the inevitable seeds of contradiction. We subscribe indeed to innumerable isms (like egalitarianism, pacifism, feminism, etc.), but they all go back to that ism of nature (i.e., the modern naturalism), which was one of the peculiar products of the Renaissance (...) we are all (...) seeking for liberty by submitting the mind to things; we are set upon mastering nature by regarding ourselves as a part of nature (...) on the one hand we have the illicit usurpation of science which came to a climax in the mid-nineteenth century, and which taught us to believe that the world runs forever in a set groove under some complex of mechanical laws, and that man like the animals is no more than a cog in the huge fatalistic machine (...) on the other hand we are haunted by a suspicion that this world of ours, so far from exhibiting the tight regularity of the machine, is an infinite flux of accidents without calculable plan or meaning (...) some of the more courageous rebels have even sought a way of escape by claiming for the imagination a complete independence of the laws of life (...) but that is only to fall from one absolute into another, to exchange servitude for vacuity. There is one door of true liberty, and that is by the way of humanism of which Aristotle long ago was the spokesman. ${ }^{23}$

This part of the Humanists diagnosis of modernity remains, by and large, in accordance with Hulme's statement, quoted above, on the "pseudo-categories": We do not see them, but see other things through them. And what is true for all contemporary spiritual and intellectual pursuits is relevant in the study of politics, too. The important thing to emphasize is that the range of political discourse in the first decades of the $20^{\text {th }}$ century was much wider than today. It was long before the pronouncement of "the end of ideology," and many different political expressions of the "conflicting theories of life" (Bolsheviks, anarchists, fascists, revolutionary conservatives, and the like) were commonly treated with all seriousness. There are very good reasons, of course, not to treat them so seriously anymore these days. Nevertheless, we should realize the measure of the Humanists' achievement: they were able to break through the layers of discourse to reach the ground level of the whole structure of modern thinking; able to see the forest - just when so many overgrown trees would draw the attention of any other observer. Even so celebrated an opposition as that between socialistic sympathy for the exploited masses and capitalist worship of the free individual proves to be superficial in the eyes of More, who says: It might seem fanciful to derive systems so contrary in tendency from the same origin, yet both are alike in that they regard the evils of civilisation as caused by that dualism of the individual and society, which was imposed upon the world as a new religion by one who sought in this way to escape the burden of personal responsibility. Both look to relief in the solution of that antinomy through the application of natural science to buman affairs and through the resulting free development of man's natural instincts, one in the direction of egotism, the other of sympathy. Nor is this difference of direction so real as may appear. ${ }^{24}$

23 P.E. More, The Demon of The Absolute (New Shelburne Essays I), Princeton 1928, pp. ix, xi-xii.

24 Idem, "Rousseau”, in idem, Shelburne Essays Sixth Series: Studies of Religious Dualism, New York-London 1909 , p. 240. 
4. Let us come to the conclusion. Humanitarianism, with its "first principles" conducive to the "horizontal" expansion of the "natural" humanity, has long since dominated modern thought and imagination, completely changing the form of civilization as we know it. This is a phenomenon of the spirit, as difficult to investigate as it is virtually all-embracing, but still, not impossible to study. It poses, from the point of view of the Humanists, a twofold danger. First, in the case of individual, we can find nothing but invitation to despair after being disillusioned by "endless" expansion. No material possession can be taken beyond the grave, and no emotional toxin can produce fruits similar to those of genuine spiritual effort. And yet, we are systematically discouraged from looking above the "ordinary self." According to More, when faith grows a little dull and the all-levelling power of democracy has brought things spiritual and things worldly to the same plane, or so at least it looks to the eyes of men, in such days the path of the individual is beset with difficulties. ${ }^{25}$ In the age of humanitarianism, the Humanist call for strenuousness, moral discipline, etc. - a call for doing hard work just on behalf of the soul, my soul - seems hardly intelligible and forever untimely. What is usual is some experience of losing orientation. The modern individual is left to drift, and bereft of the spiritual harbour. No living faith that overcomes the world. No example to follow: the example of the saints, or athletes of the spirit. No secular, or political, reflection of the "inner" religious practice through the exercise of "mediation" as taught by the Humanists.

The second aspect of the danger in question points, eventually, to the survival of the planet. That is to say, the prevailing humanitarian movement has made the very possibility of civilization highly problematic. In the words of Babbitt, the crucial question is whether one is safe in assuming that the immense machinery of power that has resulted from activity of the utilitarian type can be made, on anything like present lines, to serve disinterested ends; whether it will not rather minister to the egoistic aims either of national groups or of individuals (...) there has been an ever-growing body of evidence from the eighteenth century to the Great War (i.e., the World War I) that in the natural man, as he exists in the real world and not in some romantic dreamland, the will to power is, on the whole, more than a match for the will to service. ${ }^{26}$ As to our political thinking, it means that we must be sternly realistic as regards propaganda (or whatever name we give to the modern management of opinion ${ }^{27}$ ), and also deeply aware of the common fear of the "the immense machinery of power," if not a feeling of a coming apocalypse. In Babbitt's opinion, a terrible danger thus lurks in the whole modern programme: it is a programme that makes for a formidable mechanical efficiency and so tends to bring into an ever closer material contact men who remain ethically centrifugal. ${ }^{28}$ To be sure, we cannot assume

25 Idem, "The Religious Ground of Humanitarianism”, in idem, Shelburne Essays First Series, New YorkLondon 1904, p. 252.

26 I. Babbitt, What I Believe: Rousseau and Religion, in I. Babbitt, F. Manchester, F. Giese, W.F. Giese (eds.), Spanish Character..., pp. 231-232.

27 Cf. W. Lippmann, Public Opinion, New York 1997, passim.

28 I. Babbitt, Rousseau and Romanticism..., p. 331. 
that technological advances make people more "concentrated," or more rational and "humanistic." So, the disillusion at the level of civilization - the discovery, namely, that humanitarian schemes in politics serve the stronger - may be perceived as a beginning of global decadence which can easily bring about totalitarianism of any kind. If you live in fear of other people and their weapons, why not choose your own Napoleon, or build a bomb?...

Now, we cannot continue to dwell at length on the Humanists' diagnosis of modernity. Rather, we should give a hint as to how their thought can help us to understand our situation as "Central Eastern Europeans." The key point has already been indicated: there is a need for political realism. However, this ought to be a type of realism ${ }^{29}$ based on philosophical insight into the question of civilization vs. barbarism. We have to consider not only current economic or military issues, but the whole spiritual dimension of political thinking, or political imagination, as well. We need to have divers, nay, dive-masters in the ocean of ideas that shaped the world as we know it. We need to provide them with an appropriate education. And to this end, we need to be bold towards humanitarian discourses.

On the one side, there is the West. Not the West of our dreams, but of real consequences of the humanitarian movement which was initiated there. The modern "religion" of humanity has long ago become the tradition of that land. And despite the fact that a great many attributes of the previous civilization had been taken over, the foundation of the entire building stemmed from the discontinuity: the abandonment of the soul. The outcome of "sham spirituality," or "new dualism," is now embodied everywhere, whether we look at the current "European" ideology or examine mass culture. Here, we must navigate between dishonest claims on the promised future and fading splendours of the broken past. Not expecting "love" from our "friends."

On the other side, there is East. For the "Central Eastern Europeans," this means primarily Russia, or the russkiy mir ("Russian World"). It is not our task here to make conjectures about what Mr. Putin has in mind, or what can happen if the Russian (Slavic) demographic disaster cannot be stopped. Instead, we should ask: is there something like the Eastern alternative for humanitarianism (and Western barbarism)? The simple answer is: no. At least, we cannot indulge in a vision of non-humanitarian or pre-modern forces to the east of us. We know it only too well, insofar as we remember and we do remember - the Soviet Union's presence in the region. Yet the catalogue of Soviet crimes is one thing. The other thing is the Soviet-Eastern experience of modernity. It was an empire that tried to "bury" the West; one may say that they took unprecedented efforts to take over the reins of the modern world. They lost because they merely happened to be too weak - economically, but also with regard to political imagination. As judged from the perspective of humanism, Western mythology has proven to be stronger and more effective than anything produced by the Soviets. "Star Wars" was better than Chapayev. Now, during the Cold War as well as afterwards, and notwithstanding superficial differences, there is the continuity between Moscow and

29 Cf. idem, Democracy and Leadership..., pp. 315-316. 
Western capitals just as there is the discontinuity between them all and, respectively, civilizations of both West and East. It may be argued that the "Russian World" of ideas must not be reduced to what Lenin, Stalin, or Brezhnev represented. Certainly so; but the humanitarian movement in Russia has a long history, anyway. Leo Tolstoy, for example, was called by More "pessimist and fanatic and barbarian" 30 due to his substantial contribution to humanitarianism as a whole.

If there is a special trait of the "Central Eastern European" experience, it will have something to do with the experience of modern empire - from without. As seen from our perspective, such an empire never belongs to us, and is ever likely to become dangerous to us. True, our countries and traditions differ, yet we share - and may enhance the expression of - this peculiar mode of historical awareness. And right here, the teaching of the Humanists falls into place. The modern empire - which is, in a sense, just a bigger counterpart to the expanding individual - leans on the humanitarian ideas and rhetoric that justify its claims. To say the least, congruence between real goals of imperial (imperious?) politicians, "experts," or managers, on the one hand, and glorious prospects for the masses - especially of "provincial" nations, like ours - on the other hand, is not something to be taken for granted. These goals and justifications must be studied in their spiritual nakedness, and as such, studied seriously.

All in all, the truly important distinction is not between the West and the East, or anything like that, any kind of mixture of geography with sentimentality. The important distinction is the one between civilization and barbarism. Wherever there is a lapse into barbarism - which means, in the modern context, a lapse into a humanitarian utopia or a humanitarian dissipation, with the accompanying terrible phenomena of totalitarianism or imperialism - it must be taken into consideration. And these our considerations - our intellectual discourse over political values and political stages - should finally serve to reshape "Central Eastern Europe's" political imagination at the level of popular opinion. We must strive to get rid of the naivety and submissiveness of our peoples. A genuine self-confidence should be regained - that is, self-confidence which has nothing in common with self-indulgence, vain flattery, or joyful vulgarity, but derives from the "vertical" orientation and sound leadership. What is needed, moreover, is a notable experience of the spiritual quest, which means, in practice, learning from Western (and Eastern) mistakes and seeking our own solutions. As for now, we have enough experience of credulous faith in modernity and thoughtless imitation of those who are apparently "more modern." Bluntly speaking, our question is how to pay less for being modern. If we could thus participate in making real decisions for the world, that would be the best option. Whether with the present West (or East) or without them.

30 Cf. P.E. More, “Tolstoy; Or, the Ancient Feud Between Philsophy and Art”, in idem, Shelburne Essays First..., p. 194. 


\section{BIBLIOGRAPHY}

Babbitt I., Democracy and Leadership, Indianapolis 1979.

Babbitt I., "Humanism: An Essay at Definition", in N. Foerster (ed.), Humanism and America: Essays on the Outlook of Modern Civilization, New York 1930.

Babbitt I., "Humanistic Education in China and the West", The Chinese Students' Monthly, vol. 17, no. 2 (December 1921).

Babbitt I., "Interpreting India to the West", in I. Babbitt, F. Manchester, F. Giese, W.F. Giese (eds.), Spanish Character and Other Essays, Boston-New York 1940.

Babbitt I., Literature and the American College: Essays in Defense of the Humanities, BostonNew York 1908.

Babbitt I., Rousseau and Romanticism, Boston-New York 1919.

Babbitt I., "What I Believe: Rousseau and Religion", in I. Babbitt, F. Manchester, F. Giese, W.F. Giese (eds.), Spanish Character and Other Essays, Boston-New York 1940.

Hulme T.E., Read H., Speculations: Essays on Humanism and the Philosophy of Art, LondonNew York 1936.

Lippmann W., Public Opinion, New York 1997.

More P.E., "Academic Leadership", in P.E. More, Shelburne Essays Ninth Series: Aristocracy and Justice, Boston-New York 1915.

More P.E., "Definitions of Dualism", in P.E. More, Shelburne Essays Eighth Series: The Drift of Romanticism, New York-Boston.

More P.E., Harris C.M., The Jessica Letters, An Editor's Romance, New York-London 1904.

More P.E., "Rousseau", in P.E. More, Shelburne Essays Sixth Series: Studies of Religious Dualism, New York-London 1909.

More P.E., The Christ of the New Testament, Princeton 1924.

More P.E., The Demon of The Absolute (New Shelburne Essays I), Princeton 1928.

More P.E., The Religion of Plato, Princeton-London 1921.

More P.E., “The Religious Ground of Humanitarianism”, in P.E. More, Shelburne Essays First Series, New York-London 1904.

More P.E., “Tolstoy; Or, the Ancient Feud Between Philosophy and Art”, in P.E. More, Shelburne Essays First Series, New York-London 1904.

Murry J.M., The Evolution of an Intellectual, New York 1920.

Strauss L., "Social Science and Humanism", in L. Strauss, Th.L. Pangle, The Rebirth of Classical Political Rationalism: An Introduction to the Thought of Leo Strauss, Chicago-London 1989.

Dr Pawel ARMADA - received his doctorate in political science from the Jagiellonian University in 2009. He currently works as independent scholar on the history of Western political thought. He is the author of Szkota myślenia politycznego Leo Straussa (2012) and Humanizm jako realizm. Trzy szkice wokót myśli Paula Elmera Moréa i Irvinga Babbitta (2019), and one of the co-founders of the Lethe Foundation. 